\title{
Upcoming Transitions in the Energy Sector and Their Impact on Corporations Strategies
}

\author{
Jose M. “Chema” Martínez-Val Piera \\ ETSI Minas, Universidad Politécnica de Madrid, Madrid, Spain \\ Email: chemaval@gmail.com
}

Received 20 March 2015; accepted 18 June 2015; published 24 June 2015

Copyright (C) 2015 by author and Scientific Research Publishing Inc.

This work is licensed under the Creative Commons Attribution International License (CC BY). http://creativecommons.org/licenses/by/4.0/

CC) (i) Open Access

\begin{abstract}
An analysis is presented on a set of enabling technologies which are opening new routes for energy conversion and consumption. This portfolio of innovations is complemented by a new framework in hydrocarbon production. This integration yields an optimization of energy uses that can result in lower greenhouse gases emissions and expand the lifecycle of current available resources. These options are confronted with the need for higher quantities of energy, at affordable costs in order to maintain the economic development. The conclusion is that there are no contradictions among the general objectives in global energy policy and the goals of corporations. Companies can take advantage of their previous expertise to remain competitive, but have to further develop new skills to operate in a new energy sector that is likely to be highly interlinked; evolving for the previous model that had markets segmented by specialty. New goods, such as the electric vehicles or the advanced high temperature high power fuel cells for generating electricity, should pave the way for a more synergetic and efficient energy sector.
\end{abstract}

\section{Keywords}

Energy Enabling Technologies, Integral Energy Efficiency, Hydrocarbon New Uses, Electrochemical, Thermal Hierarchies

\section{Introduction}

A minimum of $\$ 20$ trillion investments is estimated for the next 25 years to meet increasing energy demand and to offset the declining reserves hydrocarbons [1] [2]. This is an indicator of the challenges that the sector has to address. Further, local and global contamination is posing a severe problem, which will be intensified as the number of cars increases from a circa 1 billion to 1.7 billion.

Such a global market expansion will concur with a wide portfolio of new technologies that can produce a solution to the otherwise inevitable energy crisis [3]-[5]. This solution will have to go beyond alternative and re- 
newable energy and embrace the economic harvesting of remaining oil and gas resources, including the so called unconventional.

New trend in energy and currency accounting is likely to appear. This will take into account the efficiency of different technologies and the fit among sources, technologies and end-uses. Such scenarios could be characterized by the Integral Energy Efficiency (IEE), a concept presented in this paper. The IEE can be used to find the optimum cost-benefit ratio at a global scale, at a given, worldwide.

If such a deep transition materializes, industrial corporations will have to undergo changes in structure, scope and methodologies. This will be both a threat and an opportunity [6] [7].

Energy policies are primary established at national level. Basic principles apply everywhere: security of supply, environmental quality, and minimum cost. The latter is, however, an incomplete concept if a time frame is not defined during cost minimization. Most of the policies are established only considering a very short term (i.e. four years or less).

Spain can be taken as an example, notably for the electricity industry [8]-[13]. The boom of renewable energy sources was the consequence of a generous framework of feed-in tariffs established in the Royal Decree RD 661/2007. Collateral effects of this subside based policy [14] have become a notorious problem to maintain a proper balance between the economy and the profits of the system.

When the energy problem is addressed with a longer run perspective, underlying uncertainties are too broad as to enable the reach of the optimum solution in terms of energy policy. Moreover, collateral effects can appear in policies implementation, and correction measures must be enforced. A similar problem regarding uncertainties appears in the elaboration of a paper on these subjects. Some of the relevant variables are not of physical nature, but rather evanescent and quickly fade or disappear. These variables are related with geopolitics, financial pressures on a currency, environmental trend, ideology and other social developments.

A technical analysis can be aimed at optimizing a given energy problem with defined boundary conditions [15]-[17]. However, the result can become useless because of the interference of the evanescent variables, which usually appear with enormous strength over short periods of time. They are crucial in actual life, but they are almost not admitted in a technical paper. If a paper dares commenting this type of evanescent variables, the paper risks to be deemed unsuitable for standard scientific publications, where the formal procedure has been established according to the scholar tradition.

Let us consider the problem of Global Warming and the risk of increasing the atmospheric greenhouse effect by methane emissions. Methane has a Global Warming Potential that is 70 higher than $\mathrm{CO}_{2}$. However, accounting of methane emission is much less accurate than that of $\mathrm{CO}_{2}$. The latter comes from chemical combustion, and $\mathrm{CO}_{2}$ emission rate is directly calculated from fuel composition and stoichiometric balance. On the contrary, methane can come from natural reservoirs, leaks from gas-pipes, or leaks from extraction and production process. These mechanisms do not have proper instruments for measuring the potential flow of methane.

In 2007, Global Warming [18] was so high in the cultural agenda that the Nobel Prize for Peace was awarded to the former US Vice President, Al Gore, and the Intergovernmental Panel on Climatic Change (IPCC). Seven years later, the IPCC is less emphatic in the declaration that "unambiguously, there is relation between human activity and climatic change”. Moreover, President Obama's Administration is favoring fracking [19]-[21], as a way to reach energy independence which represents a milestone in the US international policy. A reliable estimate of methane leaks from fracking-based gas production is not available, which means that the famous "IPCC scenarios” for reaching a certain level of temperature rise must be revisited.

Such abrupt and evanescent changes in energy policy from the biggest economic power in Planet Earth is rather difficult (i.e. almost impossible) to model in any scientific analysis [22] and it is, however, second to none in terms of ranking of critical variable.

From the point of view of methodology, the difference between physical variables and evanescent variables is similar to the difference between "optimization process" and "decision-making process". To optimize a system, this must be well known and comprehensively defined so that a minimum and/or a maximum can be found (including local $\mathrm{min} / \mathrm{max}$, or a saddle point).

When uncertainties ranges and evanescent variables dominate the description of the system, optimization techniques cannot be applied. In such circumstances different methods must be used, from fuzzy logic to purely stochastic.

In scientific attempt to express all internal relations of a system in terms of integral-differential equations, evanescent variables are usually omitted because they disturb the ideal picture we can get from the energy world, 
and compromise our goal.

In the presentation of the work pursuing the goal of dissecting the energy world, I focus on the possibilities and potential of the physical mechanisms available to extract, convert or apply energy by the end user. It goes without saying that the path to the goal and the goal itself can be disturbed by an evanescent variable, but an analysis must be carried out on the basis of physical facts and laws [23] [24].

In this context, we propose a new concept to complement the guidance of energy policy making, which is the Integral Energy Efficiency. IEE should lead to maximize the total amount of End Uses of Energy, compatible with a minimum cost at a global scale (relative to the produced benefit).

In this paper, this concept is analyzed considering that some of the enabling technologies currently under research will actually achieve industrial maturity. Hence, opening the energy sector to more degrees of freedom to optimize global efficiency. Those technologies would include deep changes in the transport sector. For instance, the current dominance of petroleum products could be challenged by other hydrocarbons and biological products [25]-[28] or other sources of energy (i.e. the electric vehicles).Energy storage would represent a fundamental element in such long term energy scenario. It is therefore mandatory to analyze the role and features of corporations in a much more integrated Energy sector. The classical objective for a corporation is to achieve a niche in a given market. Very likely, a further objective of the corporation will be to consolidate and/or enhance that market quota. However, both the framework and the boundary conditions for energy corporations will not be the same as those experienced in the past. This is why the analysis pays attention to the problem of fitting corporation skills to future energy sector requirements, and accounts for alternative tools to deliver energy policies in the near future.

It seems we are in a crossroad similar to that the energy sector was in mid-seventies of the 20th Century. At that time, new agencies and developers were created (i.e. the Energy Research and Development Administration (ERDA) later substituted by the Department of Energy). Technology was one of the key elements for these types of agencies. However, one should underline that some of the most relevant enabling technologies have not being provided by these institutions, but rather by independent initiatives such as the case of fracking [29]-[31].

In order to analyze the world of energy, we will study in Section 2 the current situation, which is fast evolving [32] [33]. The (re)evolution is catalyzed by technology, and the influence of higher efficiency of the energy conversion chain, from raw sources to end uses. Efficiency is the subject of Section 3. Section 4 is devoted to review technology, which is the main driver to change the Energy world. Section 5 deals with the different scenarios identified according to the priorities in the energy policies, which mean that some scope for evanescent variables is needed. Special attention will be paid to the case of unconventional gas (and oil).

The paper ends with a collection of prospects that could be derived from attempts to improve significantly the utilization of available energy sources, which can then open a new age for corporations prepared to meet these opportunities.

\section{The Current Energy World: Crossroads or Road-Maps?}

There are several studies and series of analysis [1]-[4] devoted to a better knowledge of Energy. The same facts are presented to argue in favor different points of views. The International Energy Agency tries to offer a more eclectic landscape of energy, without pushing it to extreme opinions. The European Union has to integrate different views on topics such as Nuclear Energy, but it is generally well aligned with environmental matters (i.e. Directive 20/20/20 [34]). Furthermore, the EU has a taste for technology and development, but lacks establishing strong priorities (i.e. the Alternative Fuel Directive).

The US has adopted recently a much liberalized position in the energy market, and has shown a lot of interest in energy information [3] (http://www.eia.gov/forecasts/ieo/). The US has demonstrated very limited interest in developing new energy technologies in recent years. However, several institutions have produced interesting analysis on the true values of energy research for the long run (i.e. the IEEE [4] with the document USANEPR-2014). This long-run advantage seems to be of secondary importance for the current Obama administration as compared to those related with lowering cost and providing higher energy independence (i.e. the unconventional hydrocarbon industry). The 20th Century ended with an international concern about the long term case, and a quest for sustainability was launched to avoid Global Warming [35]. As already quoted, an international body, the IPCC [36], was created to produce forecasts on climatic for the coming decades. This effort was not match to foresee problems in the Energy sector and much less to identify pathways to development markets and technologies. 
It is true that an organization as the International Energy Agency is already making forecast about the evolution of the sector, but the IEA only has 29 members, most of them from the European Union, but unfortunately not the EU as such.

We are already aware that Climatic Change deserves attention at the highest level, but Energy is not a minor problem. Energy in turn is dominating the environmental impact at every scale.

Energy is at a manifold crossroads where several concepts open different lines, especially the following ones: sources, investment, technologies, environment, sectors, emerging countries demands, independence, markets, and efficiencies.

A minimum of $\$ 20$ trillion investments is estimated by the IEA for the next 25 years to meet surging energy demand and to offset the declining reserves and production of the world's major oil fields. These numbers can be challenged; both as a whole and as an aggregation of sectorial figures. However, they are based on projections that are easier to accept. For example, the rise in the number of automobiles in the world goes from circa 1 billion to 1.7 billion.

There is, however, another set of unknowns behind these numbers. For instance, automobiles will not be the same ones as those of present days. Automobiles will be used in a slightly different pattern. People tend to live in macro-urban areas and the use of car mainly in that environment can be substituted by public transportation. As a matter of fact, as seen in Table 1, IEA [1] projections on total consumption in transportation for 2030 (and even for 2050) do not change.

Some of the hypotheses underlying in those numbers can be challenged. The forecast for Light Road values in 2050 is based on the following allocation based on energy:

- Oil products, 20

- Natural gas, 1

- Biofuels, 11

- Electricity, 7

This projection considers a very short penetration of Electric Vehicles, and this is even more relevant as it includes $\mathrm{H}_{2}$ vehicles in this source type.

As presented later, the EV presents very appealing features in fuel consumption and environmental quality. The main limitation on range should not be considered a burden as $85 \%$ of the mileage done by private cars corresponds to daily round-trips under $150 \mathrm{~km}$.

This subject will be dealt with later; it is at the very center of a potential revolution in town transportation modes and air quality. It seems to be extremely difficult to calculate the cost of environmental consequences, specifically in terms of health problems as a result of micro-particles aggression. This hazard can only be dramatically reduced by electric cars.

The Future of Energy will be the result of a confrontation among facts from Nature, political principles \& programs; and the evolution of both technology and society. Figure 1 presents a comparison between the current North-American model and the European model on the basis of a 4-corner ring where the energy battle takes place.

Nowadays, the North-American masterpiece is the new aggregation of reserves which appear in the inventory thanks to hydraulic fracturing in horizontal wells, an enabling technology which has changed at depth the oil and gas industry both in the US and at a worldwide scale.

Table 1. Total world final energy consumption in transportation (EJ) for several modes and years (source, IEA).

\begin{tabular}{cccc}
\hline \multirow{2}{*}{ Mode } & \multicolumn{3}{c}{ Year } \\
\cline { 2 - 4 } & 2011 & 2030 & 2050 \\
\hline Heavy road & 26 & 27 & 29 \\
Light road & 51 & 49 & 39 \\
Rail & 2 & 3 & 5 \\
Air & 11 & 12 & 13 \\
Sea & 10 & 12 & 13 \\
TOTAL & 100 & 103 & 99 \\
\hline
\end{tabular}




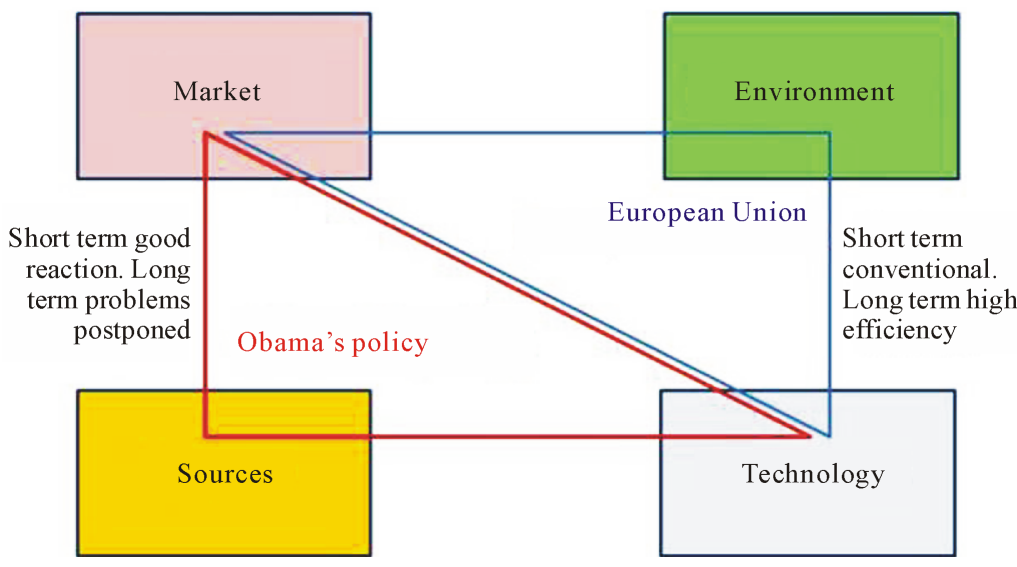

Figure 1. Sketch of the energy policy priorities in the US and the EU.

Breakthroughs in technology can be fundamental pieces in shaping the future. Nuclear Energy was an example in the past; and Shale hydrocarbons are an example right now. The Future of Energy will also be affected by changes in the demand side, but this is still harder to predict. Some of the new products and new activities, as widespread communication and digitalized information, can create new consumption modes (relying on electricity) and can save energy because they reduce the need to move for peoples and documents.

It is worth pointing out that IEA estimates predict a huge increase in energy consumption from the chemicals and petrochemicals industry. Increasing from $40 \mathrm{EJ}$ in 2011 to 80 in 2050. The remaining industrial sectors do not undergo a similar rise. Furthermore, this industry has an important peculiarity: it uses hydrocarbons as primary matter, not only as fuel. This fact points out the importance of preservation of hydrocarbons for the highest added value end use, and it is an advice for looking to petro-chemistry with greater interest.

Such a dual role of fossil fuels is not shared by the rest of electricity energy sources, namely renewables and nuclear. In particular, the success of oil products for powering vehicles comes from one of their important properties; the high energy store capacity in terms of amounts of energy per unit mass and/or unit volume.

However, efficiency of Internal Combustion Engines (ICE) is very small as compared to other energy conversion machines (i.e. turbines). That fact was not important when oil was cheap and abundant, but is becoming a problem, from economical to environmental. ICE plus oil products were a very good tandem for powering vehicles, ships and airplanes, but such a good fitting is not enough for the problems of a sector which has to become more efficient and clean.

Figure 2 shows the strong changes produced in our 4-corner ring from the appearance of fracking as a new enabling technology. Figure 3 has the EV as the technology driver.

Long term energy scenario will likely be more complex in its internal relations than the today's situation. Nowadays, as presented in Figure 4, the world of energy is rather specialized and segmented into compartments.

Close to $70 \%$ of coal currently goes to electricity generation, and $95 \%$ of oil goes to transport. Figure 5 portrays the long distant future, Electric Vehicles could give much more flexibility to the energy system, and oil could be used for more expensive applications (i.e. higher added value). This includes new energy utilizations, as discussed in next section.

Understanding how new scenarios can be built based on new enabling technologies is useful for guiding energy policies and to guide corporations too. This double objective will be treated after an insight into energy enabling technologies.

\section{Energy Efficiency Structure}

More than 90\% of the primary energy goes through the process of combustion; which, as presented in Figure 6, has a temperature. This is particularly relevant for thermodynamic cycles, limited in efficiency by Carnot's principle as presented in Figure 7.

An alternative to combustion is offered by electrochemistry, left side of Figure 6, which is not limited by Carnot's principle. However, it also has limitations [37] because of the generation of entropy. The theoretical 


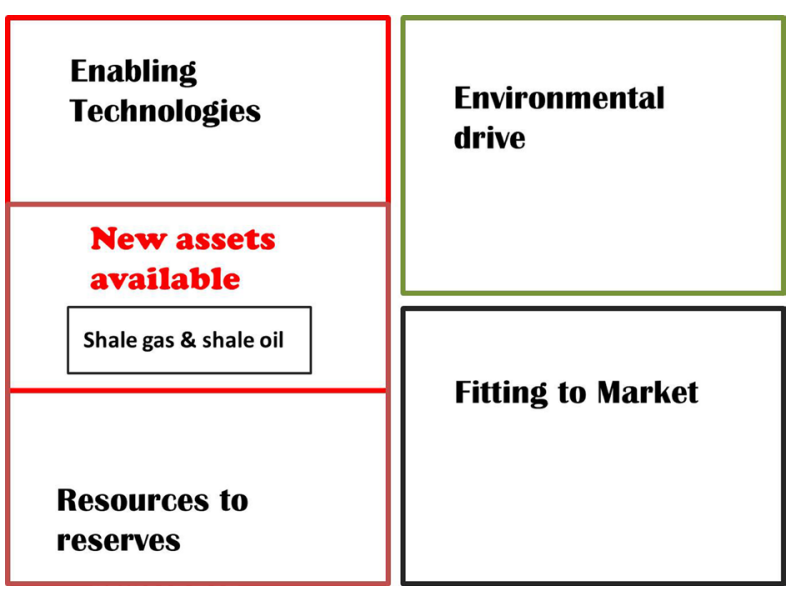

Figure 2. Four pillars of Energy and the sprout of shale gas and oil changing the scenario.

\begin{tabular}{|l|l|l|}
\hline $\begin{array}{l}\text { Enabling } \\
\text { Technologies }\end{array}$ & $\begin{array}{l}\text { New } \\
\text { products \& } \\
\text { applications }\end{array}$ & $\begin{array}{l}\text { Environmental } \\
\text { drive }\end{array}$ \\
\hline \begin{tabular}{l|l|} 
Electric Vehicles \\
Resources to \\
reserves
\end{tabular} & Fitting to Market \\
\hline
\end{tabular}

Figure 3. Four pillars of Energy and the sprout of Electric Vehicles, a key element in the future of transportation and environmental quality.

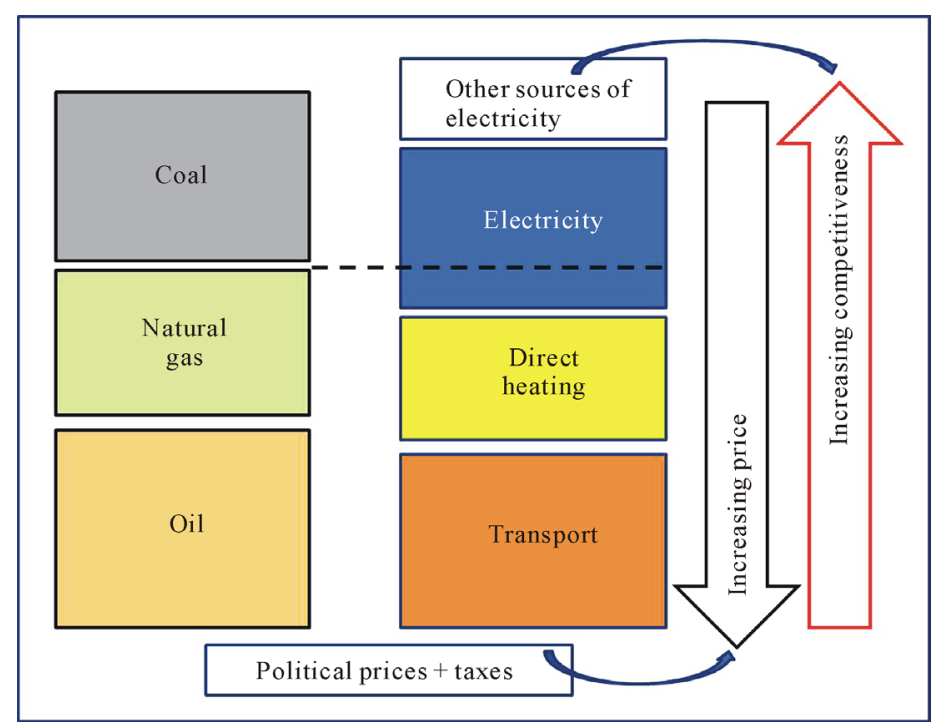

Figure 4. Fossil fuel coupling to end uses. In general, transportation presents lower competitiveness but support higher taxes. 


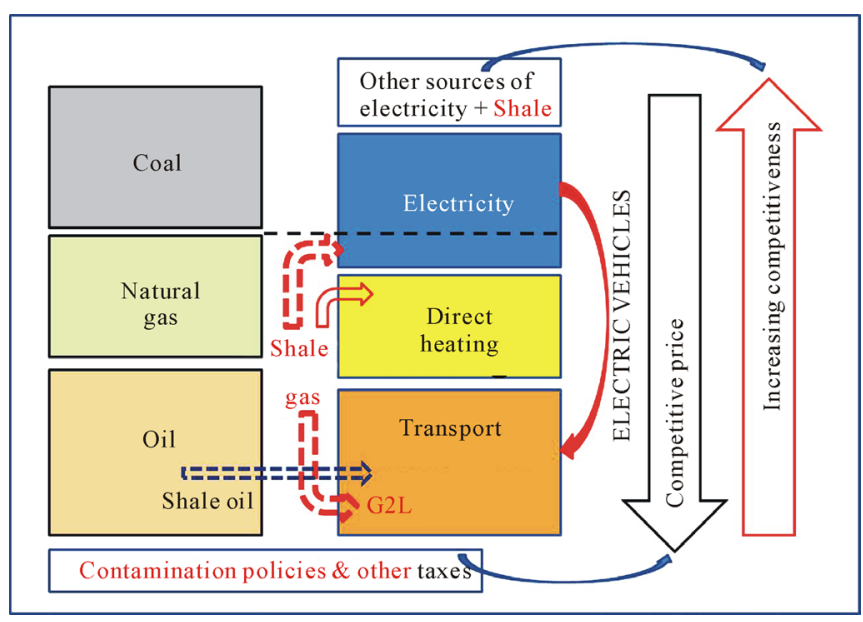

Figure 5. The deployment of Electric Vehicles will convey a deep change in the Energy sector. For instance, coal can contribute to transportation, through the electric grid, so increasing competitiveness in that field. The same can be said about electric renewable sources.

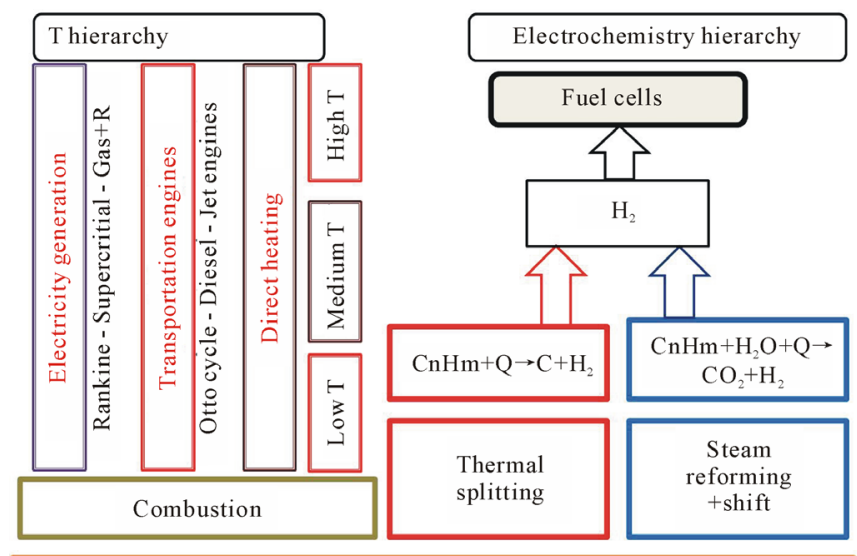

Hydrocarbons

Energy brute balance and energy quality ( + use fit-contamination) balance

Figure 6. Diagram of the pathways for exploiting the energy of the hydrocarbons. The combustion branch at left, and electrochemistry at right.

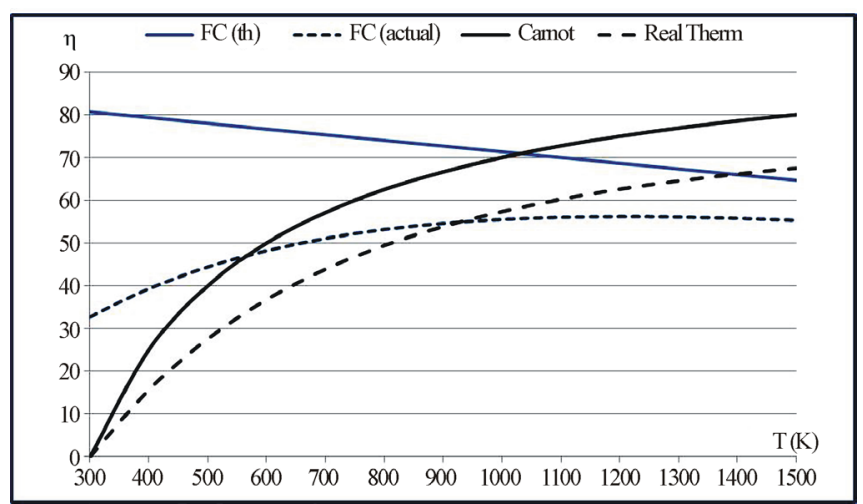

Figure 7. Fuel cell efficiency and thermal energy efficiency versus system temperature. 
limit of efficiency in this case corresponds to the ratio between Gibbs' free enthalpy $(\Delta \mathrm{G})$, and enthalpy $(\Delta H)$, and it is a decreasing function of temperature $(\mathrm{T})$, just the opposite of the thermal branch.

A first reaction to this figure is to make a complementary approach, using the brute force of combustion when high temperatures are achievable, and looking for electrochemistry devices when temperature must be low.

The latter, however, presents a hidden problem: electrochemistry needs that some electric charges (electrons and ions) move over an adequate substrate. This substrate can be a liquid electrolyte, as in lead batteries, or a solid. When moving fast, electric charges interact with those of the substrate, loss energy, and heat the substrate. Hence, if charges have to move fast because high power is needed, the system becomes very hot and efficiency decreases. This is an important rule for electrochemistry, which has been a drawback for its development [38].

Nonetheless, the development of new materials (i.e. polymer membranes) have open the way for extending the range of electrochemistry applications, including the famous case of "Hydrogen automobiles". Several studies and assessments have been conducted recently on this subject, notably by countries as Canada [39], Norway [40], and Australia [41] with very important and competitive electricity industries.

Fuel cells working at moderate $\mathrm{T}$ (i.e. below $100^{\circ} \mathrm{C}$ ) have significant lower efficiencies than the theoretical values (i.e. PEFC devices) [38]. Solid Oxide Fuel Cells (SOFC) [42]-[43] need very high operational temperatures, but they can work directly with hydrocarbons. This simplifies the previous phases of the system, with the $\mathrm{H} 2$ generator.

They are also less sensitive to poisoning by carbon monoxide and other contaminants. They could be used for electricity generation wherever gas or oil is delivered (i.e. underground in the center of a city or any remote location). Proposals based on SOFC and other fuel cells are starting to emerge [44] driven by a better integral use of the energy stored in hydrocarbons.

A different branch of electrochemistry is related to batteries, which are becoming of paramount importance for powering electric cars [45]-[49]. Main problem presented by these cars (in plug-in fully electric type) is the range. For the moment, commercial cars have a range of $200 \mathrm{~km}$ with a specific consumption of $12 \mathrm{kWh} / 100 \mathrm{~km}$ (more expensive models can double this range).

Another concern is the time required to recharge (aka speed).Batteries don not cope well with high electric energy rate over a short time. A high fraction of the energy is transformed into heat. Therefore, electric cars appear as machines very well suited for daily traffic in cities, provided the charge can be done at night in a proper place (i.e. a private parking site).

Efficiency in this case rises quite a lot as compared to Internal Combustion Engines. Let us take the example of an average petrol car, in moderately congested street circuit, with real consumption of 10 liters per $100 \mathrm{~km}$. This consumption is equivalent to circa 70 grams $/ \mathrm{km}$ or 0.66 moles of octane per $\mathrm{km}$; that would yield an emission of about 5 moles of $\mathrm{CO}_{2} / \mathrm{km}$. This is a mass flow of $220 \mathrm{~g} / \mathrm{km}$.

This is almost double the values required for new cars under EU legislation. However, these "administrative" values refer to ideal running conditions, for which consumption lowers to 6 liters per $100 \mathrm{~km}$ (or less), or approximately $130 \mathrm{~g} / \mathrm{km}$.

The value of the mechanical energy to drive an average car is $0.12 \mathrm{kWh}$ (i.e. $0.432 \mathrm{MJ}$ ). The heat load in the combustion of $70 \mathrm{~g}$ of gasoline is $700 \mathrm{kcal}$, equivalent to $2.92 \mathrm{MJ}$. Therefore, the actual efficiency of the average automobile is about $15 \%$.

The optimum engine performance is almost double the latter figure, circa $28 \%$. Inefficiencies of the engine out of its optimum, accelerations, and idle periods make the optimum performance decline significantly.

An electric motor has the advantage of not having idle periods, as it rests when the car stops. Its performance is very high for most of the regimes of the system, and is exceptionally controlled by power electronics. On average it can support an $88 \%$ yield. However, a correction factor due to charge/discharge performance of the battery is required. A conservative estimate can be a correction of $75 \%$. This results in an overall efficiency of $66 \%$. So its consumption (from the electric grid) is $0.18 \mathrm{kWh}$ electric per kilometer.

An additional adjustment is required before the final benchmark. We must add grid and generation losses to the latter figure. Again, a conservative estimate is a $10 \%$ of the total loss. This yields a need of $0.2 \mathrm{kWh}$ per $\mathrm{km}$ for the electric system.

Octane burned in a combined cycle Brayton-Rankine, currently yields an efficiency of $60 \%$ and it is expected that this efficiency is boosted up to $70 \%$ in the near future. Taking the latter figure (which best represents the future), we obtain a primary (thermal) energy consumption of $0.28 \mathrm{kWh}$ per km travelled (afterward) by car, which is equivalent to $1 \mathrm{MJ}$. 
This means that we will need to burn 24 grams of octane in an electric power plant to produce the required energy in electric form. This is just over a third of the direct consumption of an ICE gasoline car.

Generation of $\mathrm{CO}_{2}$ follows a parallel route. It is reduced from 220 to $75 \mathrm{~g} / \mathrm{km}$. This accounts for the energy chain after the gasoline is delivered; as neither process account for upstream emission of that delivery point.

It is inevitable to note that $\mathrm{CO}_{2}$ emissions would be much lower if the batteries were recharged with electricity from nuclear or renewable sources. In this case, full-life cycle emissions are in the range of $30 \mathrm{to} 40 \mathrm{~g} / \mathrm{kWh}$, or $10 \mathrm{~g} / \mathrm{km}$. This is one-twentieth of that emitted by the average car.

As for the cost to the end user, efficiency is not the only advantage. The price in electric domestic market are circa $20 \mathrm{c} € / \mathrm{kWh}$ (electricity), hence the cost per $\mathrm{km}$ would be $3.6 \mathrm{c} € / \mathrm{km}$, or 3.6 euros per $100 \mathrm{~km}$. With gasoline at $1.5 € /$ liter, and an average of 10 liters per 100 , the cost would increase to $€ 15$ per $100 \mathrm{~km}$. This is a fourfold increase. ON the one side, this value includes the very high tax burden to gasoline, but on the other side it reflects the price of gasoline at either high and low international prices of oil as a commodity in the international market, i.e. Brent oil. At 100,000 km the electric car would save more than 11,000 €. This should compensate for the cost of the battery and the ancillary systems.

In summary, the largest environmental cleanup in both global and local pollutants, increased energy efficiency of automobile transportation and the positive economic impact to consumers, all point out that the Electric Car is a very powerful pathway to improve overall energy arena.

Additional economy considerations can be taken into account. If a car owner decides to optimize the investment and running costs for the total requirement of car performances in a given period of his/her life (i.e. 5 years) the owner will find that more about $85 \%$ of the total distance (number of $\mathrm{km}$ ) traveled is done in daily roundtrips that are shorter than $100 \mathrm{~km}$.

Owners might dive longer distances some long week-ends throughout the year, and could engaged in few (i.e. one or two) trips a year with distances longer than $2.000 \mathrm{~km}$ (forth and back). For the latter, an air flight plus a car renting strategy saves the owner a lot of money and a lot of time, and at the same time the total energy balance is also optimized (even for a car with 5 passenger this will not be a worst scenario). An Airbus 320 spends 5.000 liters of kerosene in a trip from London to the Spanish cost in the Mediterranean Sea, and carries around 125 passengers. This means 40 liter per passenger. If driven in a usual European car, the owner will need about 20 hours of effective drive (for $2.100 \mathrm{~km}$ ), consuming about 200 liters of gasoline.

Similarly, if a depreciation of $0.5 € / \mathrm{km}$ is applied to the car, the trip London-Murcia implies a roundtrip cost of $2.100 €$. Adding the cost for fuel, the total cost of the round trip is circa $2.700 €$.

Again, the comparison with the flight depends on the number of passengers, but one can find air fares for that flight at less than $250 €$ (excluding low cost airlines). Therefore, both from a personal and an energy efficiency perspective, the optimum solution is to accommodate the features of the trip to the characteristics of the machine.

It can be argued that the cost for renting a car must be added, but this cost is significantly lower to the associated cost of three driving days for a fifteen-day holidays.

The option of renting an ICE car for long domestic week-end trips is an option that will help optimize the energy consumption over the time-span under consideration (i.e. 5 years).

It is true that ordinary people are not used to this type of calculation, but this is rather simple and one can foresee an information campaign to illustrate these calculations. All electric car vendors already have calculation schemes to demonstrate the savings associated to a given type of daily trips and other journeys. And should everything fail an app for smartphone can help deliver this advantage.

Social and cultural changes are in many cases encouraged by technology, with or without government advertisement. There was no governmental campaign to foster mobile phones or the use of Internet.

Cars are much more expensive than a phone or a computer, and the reaction time constant for buying a car is much longer than the period to replace a cellular phone. This means that this "evanescent" variable of public perception and decision making will be not as prompt as in telecommunication. However, many hints point out in that direction.

Electric vehicles can become household goods on this basis faster that they can do so by local government policies to impose them to fight local contamination.

\section{Technology Changes in the 21st CENTURY}

It is not easy to generate prospects on Energy Technology. Previous experience points out that some promising 
lines grow little by little while other lines lagging behind for many decades burst suddenly and make an early market breakthrough.

An example of the former is nuclear fusion, which 40 years ago it was considered a matter to be controlled within the forthcoming 30 years. In reality, nuclear fusion has kept in the main road of tokamak reactors but it still considering that industrial maturity will arrive 30 years from now.

An example of the latter is photovoltaics, which was considered a very expensive and inefficient technology for electricity generation, and explode over the last decade. Investment costs have decreased from over 10 to under $2 \mathrm{US} \$ / \mathrm{kW}$.

The key factor was that PV did not require a significant breakthrough in physics, but rather a development of technology. On the contrary, the control of magnetic fusion reactors was not mastered 40 years ago and there it still holds several unknowns nowadays. It is obvious that many advanced have been made, but research is still at the laboratory scale and with fundamental problems to be addressed.

The situation for renewable energies is just the opposite. These sources of energy rely on well-known physical mechanisms and the main problem has always been to reduce costs (both capital expenditures and operating costs). The best results have been achieved by improving designs and materials.

The learning curves of all renewable energy sources have been successful in the last 10 to 15 years. The first renewable energy to achieve a significant reduction of costs was wind power. It became possible to manufacture a machine (the 3 blade horizontal generator mounted on a tower) with a higher efficiency than the rest of the machines.

PV still presents many potential lines of development, although the best cost reduction step has been associated to cheap semiconductor material (i.e. poly-crystalline silicon).

Nevertheless, the new energy technology port-folio includes advancements in all levels or stages of the energy supply chain and the form of energy and its changes throughout the chain.

In terms of sources of energy, it is obvious that "fracking" represents one of the key milestones of the past years, and efforts should be done to make it cleaner and more effective in terms of the hydrocarbon recovery factor. Otherwise, some areas (i.e. Europe [50] or Quebec (Canada) [51]) will not join the fracking club.

In the energy conversion phases, electrochemistry [37] can give a boost to energy efficiency, particularly in the domain of distributed generation. Fuel cells working on very clean hydrogen [38] need a previous chemical double reactor, with one endothermic process for steam reforming and other exothermic process for shifting the reaction.

For the moment, technological advanced in this technology have been very limited. However, many possibilities can be identified in this technology option such as reactor configuration, materials, and temperature regime.

Two important aspects about fuel cells are the following: first, some fuel cells [42]-[44] run on hydrocarbons, which can easily be stored; and second, fuel cells do not have moving parts, which can an advantage for operation and maintenance.

On the other hand, experience with fuel cells is still limited if compared to the enormous potential of electrochemistry.

Electrochemistry has already been identified as a candidate for new energy technology alternatives. Electrochemistry can be considered as the most important one in terms of economic impact on environmental quality and integral energy efficiency, which is the case of the electric vehicle.

It is eloquent to revise the history of electric cars [52]-[54] which were proposed more than one century ago. The electrical vehicle has had peaks and troughs along these years. Even after the oil crisis, when some analysts and researchers propose electric cars fed by nuclear - generated electricity for coping with the energy problem. Troublesomeness for this proposal is that it took too long to develop the nuclear power park for supplying all the energy that was required, and beyond and above, the very limited range that an electrical car had at that days.

Batteries for electric cars and the cars themselves started to change 25 years ago, once electrochemistry was identified as a powerful tool for energy transformation with high efficiency. Table 2 is a good example of the efforts needed to push technology ahead, and it is homage to those who believed in Electric Vehicles when they were not yet a promise.

However, upcoming energy technology developments will affect most (if not all) segments in the world of energy. This applies for the domain of sources, its conversion, and its applications. Of course, in the short term there will be a clear priority to make natural gas the center of many fundamental decisions, particularly because of the success of fracking and other new techniques, but also because of the vast amount of resources discovered over the past years. 
Table 2. An important relic from the past: assessment on batteries for electric cars as foreseen in 1989. Projections were incomplete, but not out of the case [52].

\begin{tabular}{|c|c|c|c|c|c|c|c|}
\hline \multicolumn{8}{|c|}{ Characteristics of selected electric passenger vehicles } \\
\hline & & & & & & \multicolumn{2}{|r|}{ Projected } \\
\hline & ETV-1 & ETV-2 & ETV-20 & ETV-I & $1987 \mathrm{BMW}$ & $1990 \mathrm{BMW}$ & VW Jetta \\
\hline Top speed. mph & $\dagger$ & 62 & 60 & 60 & 53 & 75 & 78 \\
\hline Urban range. Mi & Up to 75 & 66 & $<75$ & $\dagger$ & $43-77 \S$ & $62-124 \S$ & 118 \\
\hline 0 - 30 mph acceleration secs & $\dagger$ & 8 & $\dagger$ & 7 & 14 & 7 & 6 \\
\hline Mi/kuh from battery city & 3.41 & 3.14 & $\dagger$ & 3.61 & $\dagger$ & $3.73 \|$ & $\dagger$ \\
\hline Passenger capacity & 4 & 4 & 2 & 2 & 4 & 4 & 4 \\
\hline Power train & dc & dc & ac & ac & dc & ac? & ac \\
\hline Battery & $\mathrm{Pb} / \mathrm{acid}$ & $\mathrm{Pb} / \mathrm{acid}$ & $\mathrm{Pb} / \mathrm{acid}$ & $\mathrm{Pb} / \mathrm{acid}$ & $\mathrm{Na} / \mathrm{s}$ & $\mathrm{Na} / \mathrm{s}$ & $\mathrm{Na} / \mathrm{s}$ \\
\hline Approx year of tests & 1980 & 1980 & $1986 ?$ & 1985 & 1987 & 1987 & $\dagger$ \\
\hline Reference & $\begin{array}{l}\text { Kurtz } \\
(1981)\end{array}$ & $\begin{array}{l}\text { AiResearch } \\
\text { (1981) }\end{array}$ & $\begin{array}{c}\text { Wyczalek } \\
\text { (1987) }\end{array}$ & $\begin{array}{l}\text { Ford \& GE } \\
\quad(1987)\end{array}$ & $\begin{array}{l}\text { Regar } \\
(1987)\end{array}$ & $\begin{array}{l}\text { Regar } \\
(1987)\end{array}$ & $\begin{array}{c}\text { Angelis \& Sedgwick } \\
\qquad(1988) \|\end{array}$ \\
\hline
\end{tabular}

Top speed is maximum continuous cruising speed. Range and efficiency data for ETV-1. ETV-2. and ETX-I refer to FUDS (Federal Urban Drive Schedule);for Jetta. They refer to ECE (European) urban cycle. †Not available. $\ddagger$ Range is at constant speed of 25 mph. $\S$ Lower range estimate at top speed; higher at $30 \mathrm{mph}$. ॥Based on ABB Na/S battery projections of Table 3. with an improved powertrain.

Properly speaking, fracking had been known for decades, and it was pursued in the peculiar "Plowshare Project" [55] which was conceived for extending the use of Nuclear Explosives to peaceful applications, as ultra-large civil works and underground intrusions for getting minerals and above all, getting gas from source and/or trapping rocks. It could be said that "fracking gas" was known but remained unknown for many years.

Energy conversion and customization for final uses will surely be another domain for development and novelties. Notably in the process of becoming more dependent on electricity for many applications, including a substantial part of ground transportation in private vehicles.

Fuel cell, batteries and combustion will have to come closer to enable synergies that we are currently missing. Integral Energy Efficiency it is somehow dependent on those synergies.

Currently, oil products are mainly consumed in Internal Combustion Engines with a theoretical efficiency circa $30 \%$, but with a real efficiency in the range 15 to $20 \%$. This is in full contradiction with the inherent capabilities of a chemical fuel, which could burn at $1500 \mathrm{~K}$ and above, so creating a very hot energy source. Of course the main feature appreciated in liquid oil products is their capability to store energy in small volumes. This is just the end of the string respect electricity.

Electric engines have very high efficiencies (from plug to shaft) but electricity cannot be stored. A potential way to avoid this mismatch is to rely on hydrocarbon-fueled high temperature Fuel Cells in order to generate electricity with a very high efficiency that will later be used to recharge batteries. Of course it is not possible to assemble a car with a SOFC component, at is operates at $600^{\circ} \mathrm{C}$ and has a power in the order of few MW. However, it can be located in a secured facility close to consumers.

This leads to an integration of routes for energy conversion in order to optimize the Integral Energy Efficiency within the framework established by the applications. A sketch on this integration between the electrochemical hierarchy and the thermal hierarchy is shown in Figure 8.

Integrating all possible mechanisms to optimize the exploitation of energy does not disturb the energy markets. On the contrary, it aids sorting them out in a better manner. In some instances it is considered that the deployment of the electric vehicle at large scale will be harmful for the oil industry, and this is not the case. It is not so because oil has unique properties, that range from a well stablished global market to its own physical and chemical properties.

In particular it can be considered one of the best, if not the best way, to store energy. Figure 9 depicts this characteristic in comparison with Natural Gas and major Renewable Energies (Solar ones plus Wind). Oil has the largest range for accessibility (because it can be transported easily across long distances) and also has the widest range of applications (including future generation of electricity with a much higher efficiency, and lower 


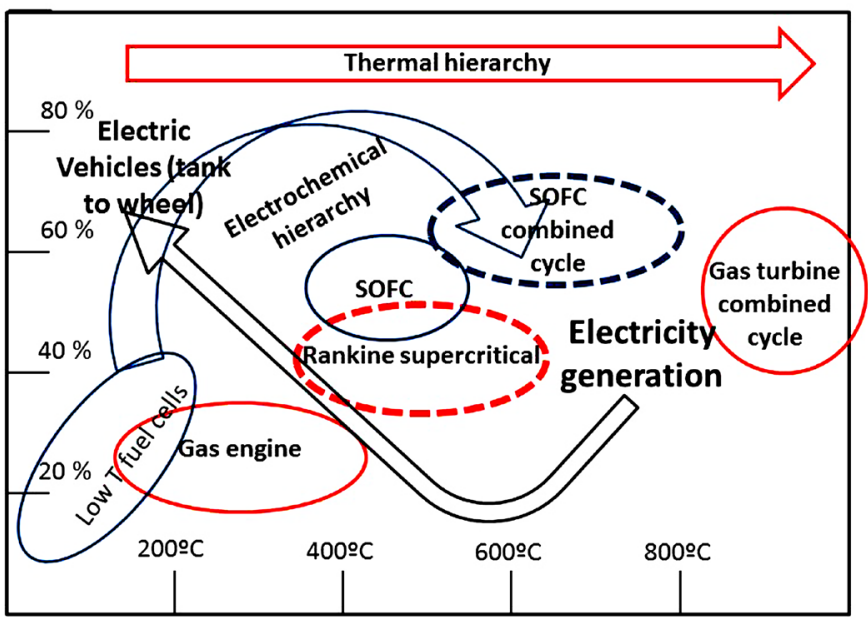

Figure 8. A map of efficiencies and temperatures for different combinations of thermal machines and Fuel cells.

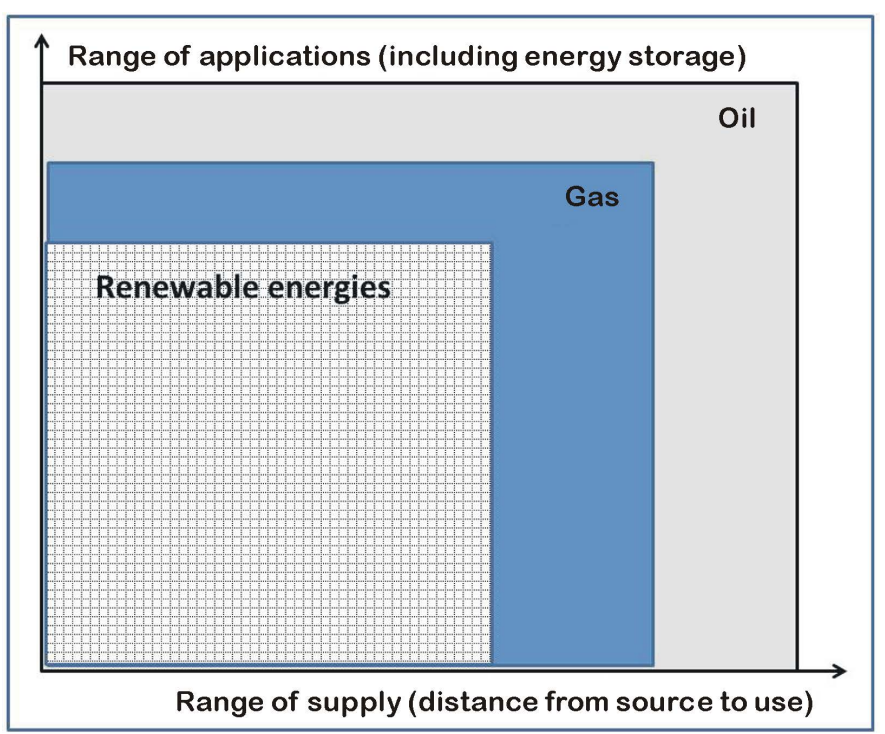

Figure 9. A qualitative graph of the ranges covered by different sources of energy in relation to supply and environment.

$\mathrm{CO}_{2}$ emissions unit of energy per consumed).

\section{Energy Policies and Corporation Strategies}

The actual evolution of the Energy sector cannot be outlined with a high level of confidence. Even in centrally planned economies, because of technology leaps, market oscillations and environmental pressure, the task of forecasting evolution of energy is hard. What can be done is to analyze specific scenarios. Relying on coherent assumptions we can identify shortage of materials, or excessive financial support to materialize. Those scenarios can be defined presuming selected evolution in relevant variables, including evanescent ones, which can come from the past in the Energy sector.

This exercise is achievable in the case of automobiles, their engines and the energy infrastructure to power them. Good projections of automobiles have been carried out in the past using specific ratios as a basis for forecasting. This is based on the relationship between the number of automobiles and total population in a specific geographical area (i.e. continents or countries), as well as other variables in relation to the number of cars (i.e. as work force and gross domestic product). The fraction of total income devoted to vehicle acquisition and fuel is 
another fundamental ratio. Last but not least, sound judgment is needed to preserve necessary coherence of the study.

The penetration of EV in a given market can be studied as an example of this procedure. This will at least highlight the different requirements on the key variables of the problem. Each scenario includes different patterns in the energy conversion chain (from sources to market) depending in this case of the type of vehicle. A conversion chain is defined by a number of steps where some energy is lost, some contamination is generated and some investments or cost must be expensed.

Some values can be assigned to different steps and patterns to qualify their maturity or readiness, but credibility of the study will largely remain a personal decision. Energy technologies still needing very basic R\&D programs as Nuclear Fusion should not be included in the picture.

The International Energy Agency, the US Energy Information Administration and the European Commission (through the Joint Research Center, mainly) have similar models for characterizing energy scenarios. The main difference among them is the role assigned to some of the new technologies.

The main deficiency for this methodology is that it cannot integrate innovations which are not yet in the agenda. The most visible example is happening now in the USA, where the "breakthrough" of fracking and shale resources has changed completely the Energy sector. Figure 10 shows the impressive evolution of "shale gas" in the USA over the past six years. This revolution deserves a suitable analysis and some further comments.

The most important one is that "unconventional gas" (and oil) is not an interim explosion in the NorthAmerican industry but a long-standing trend with important consequences in geopolitics, environmental qualification and economics of Energy. Projections of gas production in the States are given in Figure 11, where it can be seen that "unconventional gas" will be dominant from now on.

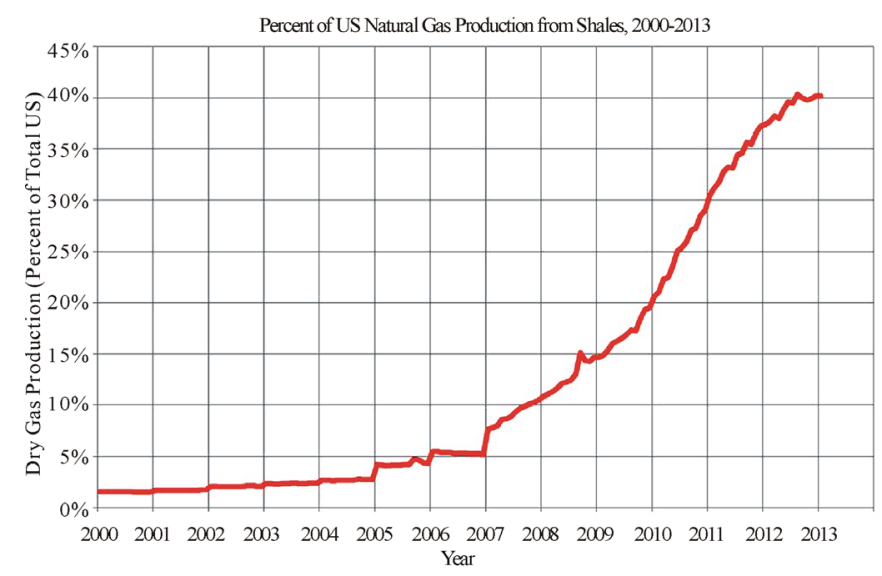

Figure 10. Percentage of shale gas production over total, in the USA.

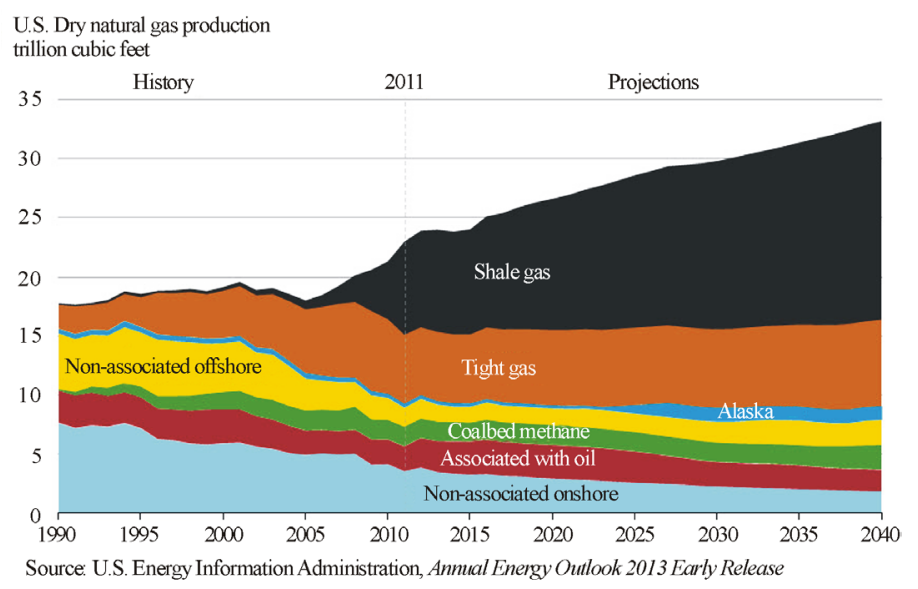

Figure 11. Share of different types of gas production in the USA. 
"Shale” was not in any official agenda, and had not been previously evaluated in environmental terms. It was a "gold rush" created by technology pioneers, sprawling immediately. The full story of “fracking” is still to be told, but we need to highlight that the US DOE was promoting other lines of action. Most of these lines are currently frozen.

The rush has been so fast that potential cost associated with toxic waste or by products are not internalized yet. The main reason for this is a lack of reliable accounting on them. Moreover, shale hydrocarbons have not yet become an international commodity but rather locally traded.

A suitable infrastructure was not available when the gold rush started, and a sort of mismatch went on between drilling and full-scale commercialization. Drilling is not cheap, and completions are expensive. However, the biggest threshold was to develop an infrastructure for exporting goods throughout the country. The core of the infrastructure was for importing crude oil and refined products, and that shift implied a change in mentality and big capital investments.

The development of that network will only take a couple of years (partially aided by the Obama's Administration support and commitment) and will start a new age (one of uncertain time duration) where oil will not be linked only to critical domains.

Important countries as United States and Canada, with huge shale reserves, can convey a lot of stability to the oil market in the mid-term, mainly in terms of supply.

This process to achieve the international market cannot be deployed faster. "Fracking" was born and grew up without asking permission, and without it being present in the energy agenda or planning.

This delay is neither good for the energy system nor goof for shale-hydrocarbons producers. Potential revenues are not realized because they do not have yet access to the global market.

Figure 12 shows the differences in price among three major gas markets. They are paramount, and they have several root causes. Access to cheap reserves is one of them, and this includes a long term of guaranteed supply.

Short term profit has been in this case the driver planning tool. The process was somehow capped; but it has not experienced a strong change, due to a change in priority in President Obama's Administration. At first, this Administration seemed very committed to global environmental issues. For example, it created in 2009 a new entity called "White House Office of Energy and Climate Change Policy”. However, it this entity did not quite deliver on its expectations as it was integrated in the "Domestic Policy Council" after two years.

Anyhow, first presidential statements clearly indicated direction in policies related to energy. In the vice-president's memorandum dated December 15, 2009, under the title "Progress report: The transformation to a clean energy economy", the driving force for those policies are defined as "jumpstarting a major transformation of our energy system including unprecedented growth in the generation of renewable sources of energy, enhanced manufacturing capacity for clean energy technology, advanced vehicle and fuel technologies, and a bigger, better, smarter electric grid.”

In fact the report is divided in the following sections: Renewable Energy, Vehicles and Fuels of the Future, Grid Modernization, Energy Efficiency, Carbon Capture, Nuclear Power, and Science and Innovation. Neither the word "shale" nor "fracking" appear in the text.

- In current times, “unconventional gas” has already been embodied in Obama’s Administration. Efforts have been made to justify it not only by private profit, but according to a philosophy established on the following points: "Unconventional gas" can be made "sustainable” by selecting the regions where it can be exploited and establishing the corresponding regulations.

- It is a very good element to support freedom from Russian energy dependence and freedom from Persian Gulf oil dependence.

- Unconventional gas profits will have to be invested, in a sizeable fraction, into Clean Energy Projects.

Industrial and commercial corporations, as anyone else, live in a certain social and legal environment, including technical regulations. A specific feature of corporations is their strong dependence of being profitably fitted to that environment. Adaption is important for any living being, but it is even more critical in companies. Companies can easily be created or discontinued according to decisions made by investors, who act as watchdogs for corporation profitability. Although each corporation has its own internal structure, coherent to its objective, a generic description of its functional articulation can be depicted as illustrated in Figure 13.

Money (and Profit) is usually the criterion to assess the health of a corporation. However, some intangible assets (such as know-how and expertise) should also be evaluated in terms of potential profit for the future.

If money is the outermost shell which is indeed connected to the general financial system, the Physical Assets 


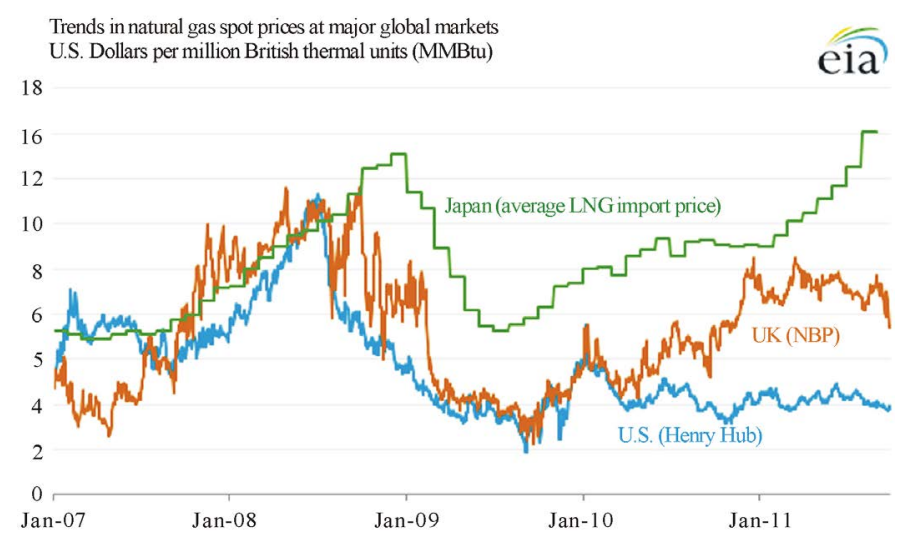

Figure 12. Differences in price among three major gas markets.

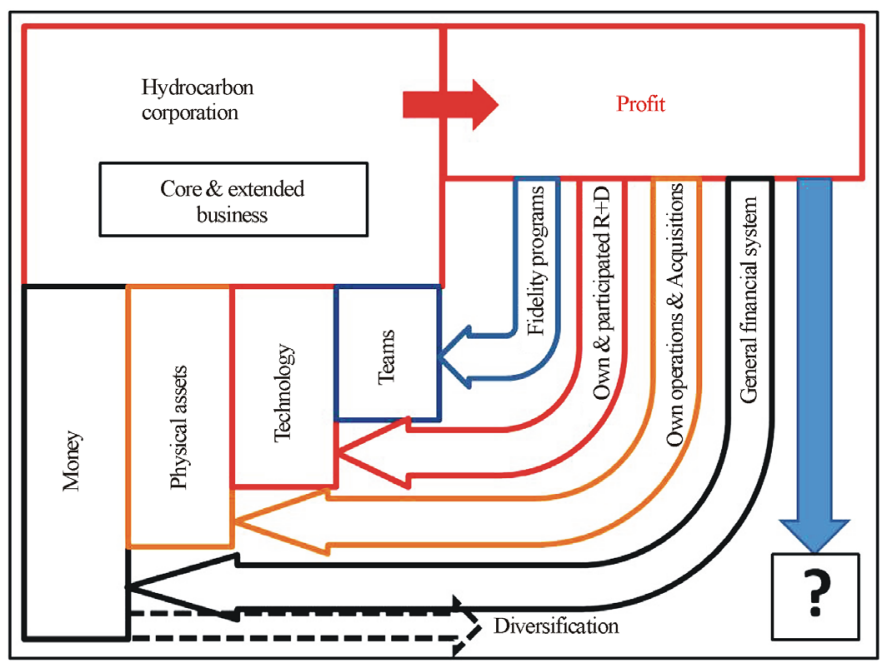

Figure 13. A schematic flowchart of activities in a corporation.

of the company, acquired along its history, constitute the bones of such particular body.

Technology is the third shell of the company; and a clear distinction can be seen between this shell and the Physical Assets: these ones are private property of the corporation, and Technology is in many cases a "cloud" of knowledge, which can be partially protected by patents and other rights, but it is created out of scientific and commercial knowledge, and it can therefore evolve and be improved.

In the innermost shell we find the people, or teams, of the company. They can go out as they can come in, and properly speaking are not assets of the corporation, regardless of confidentiality clauses.

People however, constitute the nervous system and the brain, and this is why the so called "human factor" is so important. This is none the less outside the scope of this paper.

The objective we had when setting the foundations of this work was to analyze the main features of the evolution of Energy macro-policies, and to analyze how Energy corporations should do for being successful in the new Energy scenario where it will have to compete. , which includes a long series of influences characterized booth by physical and evanescent variables.

The answer to this question is very complex, and in some cases will not exist as such, and it will be a collection of considerations and advises coming from the general analysis of the Energy sector.

A Directive from the European Union "European alternative fuels strategy" (COM) 2013, 17) requires Member States to adopt national policy frameworks to development markets for alternative fuels and develop their infrastructure. The Directive sets binding targets for the build-up of alternative fuel infrastructure. An accompanying Impact Assessment (SWD (2013) 5/2) evaluates cost and benefits of different policy options and identifies conditions for a comprehensive coverage of the main alternative fuel options. 
The assessment is aimed at being totally neutral in both economics and technology terms. This boundary condition limits drastically the scope of the assessment. The Directive in opens all possible ways (different from the classical ones) and does not attempts to define a priority list of actions based on a given number of criteria's. The Directive seeks insight of long-term potential, environmental impact, security and flexibility of energy supply.

It does not mean that a corporation has to deal with all possibilities. On the contrary, a corporation must identify the ways, means, and objectives to address the future utilizing all the knowledge and judgment acquired in the past to succeed in its quest to perform in the future world of energy.

\section{Summary and Expectations}

From any known analysis, it must be understood that there is no possibility to define and develop a unified and integrally coherent Global Energy Policy for the entire planet.

Even in the world covered by the International Energy Agency, a unique policy seems out of reach. Nevertheless, corporations can be oriented by analytical approaches to the scenarios envisioned by the prospective work done by several agencies and the proper central team of the corporation and external specialized consultants.

Scenarios identified in this analysis as potential integrations of coherent choices are depicted in Figure 14. Business as usual should not be considered as an option, because it is impossible to ignore the strong changes in technologies and markets. It is a BUS going nowhere.

Environmentally dominated scenarios seem rather unlikely, because they will be very expensive and would only be meaningful if all countries accept the same procedures and standards. This is very unlikely based on the aftermath of the Kyoto Protocol.

Integral optimization of energy seems the most sensible scenario for a more efficient future. It has the very important appeal of advanced technology. At the same time, it has the drawback of expensive investments to deploy new technologies. The key advantage is that the system will be more effective in the long run, reduces fuel consumption, and reduction collateral side effects (as those produced by contamination of combustion byproducts) All these will represent a major benefit which will likely overwhelm the initial drawback of higher expenses. This scenario follows the typical law of economics of engineering systems: the higher the investment cost (a proxy to higher quality) the smaller the running cost, especially fuel costs.

Last scenario shown in the picture is the most aggressive one, and corresponds to a general deployment of fracking. Local and global opposition to fracking can disturb this course of action. It is certainly not a well-accepted option within the European Union. It has been briefly explained that this is mainly a North-American story, and a rather fast one. The "fracking" technology has got such momentum that Obama's Administration has changed its general vision of Energy.

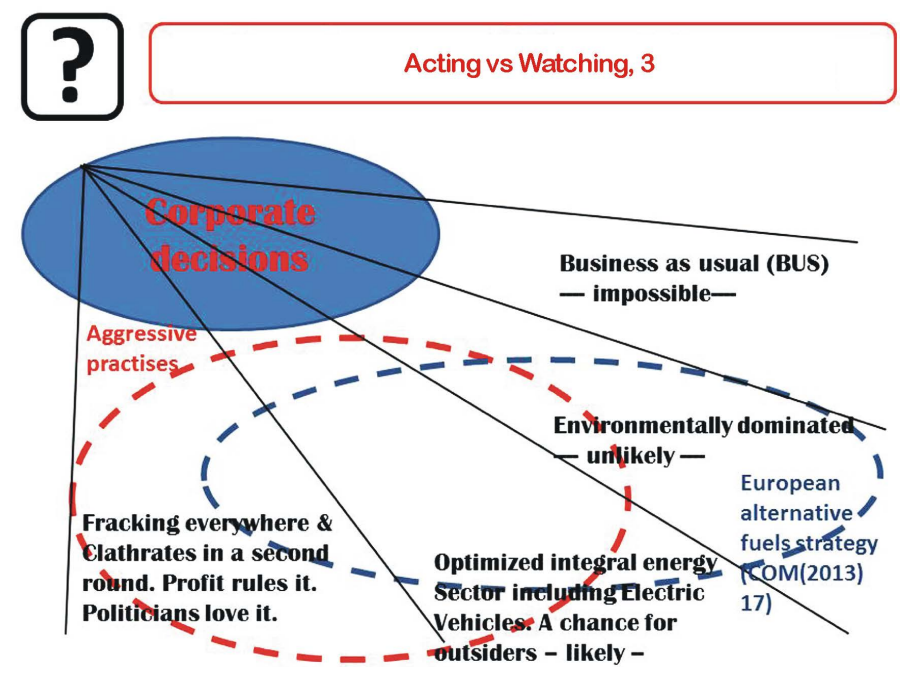

Figure 14. A map of pathways for arriving to different futures. 
After considering that fourfold pathway towards a profitable future for the Energy corporation, what advice could be drawn from the contents of this paper? It seems the advice should be to invest and rely on technology. Further, to focus on the effects that the full development of an array of well coupled technologies would have on the market where the corporation works and the corporation itself.

From all papers studies under this scope, technologies that seem mandatory in this advice are: Electric Vehicles; High temperature fuel cells; Distributed and controlled electricity generation; and energy storage.

This can be counter intuitive and somehow a paradox, but oil can contribute towards those objectives (as well as natural gas), with higher efficiencies and lower $\mathrm{CO}_{2}$ emissions per unit of energy applied to any given end use.

In other words, hydrocarbons can play a unique role in the context of Integral Energy Efficiency. Petroleum products can become the tools that guarantee the energy supply chain thanks to their suitable properties for storage and for feeding new electrochemistry devices.

This means that it is possible to make a corporation that is based on hydrocarbons operation compatible with the requirements for lowering the greenhouse gases emissions. In fact, it is possible because there are many roads for improving synergies among energy conversion mechanisms.

Hence, there seems to be a good agreement between the overall mandate of increasing the Integral Energy Efficiency as a general priority at global scale and the corporation objective of maximizing profits within a framework of commercial activity.

Corporations should be prepared for the higher complexity of future energy sector, with more degrees of freedom in a less segmented fueling structure.

\section{Acknowledgements}

This paper is part of the Ph. D work of J.M “Chema” Martinez-Val, at Madrid Technical University (UPM) in the School of Mines. The Ph. D work is carried out under the direction of professors Maldonado and RodriguezPons. He also studied at The French Institute of Petroleum and the Colorado School of Mines. He is a Registered Engineer at Texas Board of Engineering.

\section{References}

[1] International Energy Agency (2014) http://www.iea.org/etp/explore/

[2] International Energy Agency (2014) World Energy Outlook 2014. www.worldenergyoutlook.com

[3] U.S. Energy Information Administration (2014) Annual Energy Outlook 2014 with Projections to 2040. http://www.eia.gov/

[4] IEEE (2014) IEEE National Energy Policy Recommendations. www.ieeeusa.org

[5] International Monetary Fund (2012) Coping with High Debt and Sluggish Growth. http://www.imf.org/external/pubs/ft/weo/2012/02/

[6] Chema Martínez-Val, J.M., Maldonado-Zamora, A. and Ramon Rodríguez Pons-Esparver, R.R. (2013) Adapting Business of Energy Corporations to Macro-Policies Aiming at a Sustainable Economy: The Case for New Powering of Automobiles. Energy and Power Engineering, 5, 92-108. http://dx.doi.org/10.4236/epe.2013.51010

[7] Chema Martínez-Val, J.M. (2013) Improving the Global Energy Industry by Integrating Macro-Technologies: Challenges and Opportunities for Corporations. Energy and Power Engineering, 5, 604-621. http://dx.doi.org/10.4236/epe.2013.510067

[8] Red Eléctrica de Espa-A Website. http://www.ree.es/sites/default/files/downloadable/sintesis_ree_2013_v1.pdf

[9] Perez, Y. and Ramos-Real, F.J. (2009) The Public Promotion of Wind Energy in Spain from the Transaction Costs Perspective 1986-2007. Renewable and Sustainable Energy Reviews, 13, 1058-1066. http://dx.doi.org/10.1016/j.rser.2008.03.010

[10] Martínez Montes, G., Serrano López, M.M., Rubio Gámez, M.C., Menéndez Ondina, A. (2005) An Overview of Renewable Energy in Spain. The Small Hydro-Power Case. Renewable and Sustainable Energy Reviews, 9, 521-524.

[11] Hernández, F., Gual, M.A., Del Río, P. and Caparrós, A. (2004) Energy Sustainability and Global Warming in Spain. Energy Policy, 32, 383-394. http://dx.doi.org/10.1016/S0301-4215(02)00308-7

[12] Foidart, F., Oliver-Solá, J., Gasol, C.M., Gabarrell, X. and Rieradevall, J. (2010) How Important Are Current Energy Mix Choices on Future Sustainability? Case Study: Belgium and Spain-Projections towards 2020-2030. Energy Policy, 38, 5028-5037. http://dx.doi.org/10.1016/j.enpol.2010.04.028 
[13] Batlle, C. and Rodilla, P. (2010) A Critical Assessment of the Different Approaches Aimed to Secure Electricity Generation Supply. Energy Policy, 38, 7169-7179. http://dx.doi.org/10.1016/j.enpol.2010.07.039

[14] Moreno, F. and Martinez-Val, J.M. (2011) Collateral Effects of Renewable Energies Deployment in Spain: Impact on Thermal Power Plants Performance and Management. Energy Policy, 39, 6561-6574. http://dx.doi.org/10.1016/j.enpol.2011.07.061

[15] European Union (2011) Materials Roadmap Enabling Low Carbon Energy Technologies. Commission Staff Working Paper, SEC (2011) 1609 Final.

[16] European Union (2013) Guidelines for Financial Incentives for Clean and Energy Efficient Vehicles. Commission Staff Working Document, SWD (2013) 27 Final.

[17] Klaassen, G. and Riahi, K. (2007) Internalizing Externalities of Electricity Generation: An Analysis with Message-Macro. Energy Policy, 35, 815-827. http://dx.doi.org/10.1016/j.enpol.2006.03.007

[18] Intergovernmental Panel on Climate Change (2007) Fourth Assessment Report, 2007. www.ipcc.ch

[19] Terrell, H. (2011) US Gas Reserves Estimated at Record High. World Oil, 232, 13.

[20] Hydrocarbon Processing (2011) Natural Gas Enters a New Era of Abundance. Hydrocarbon Processing, 90.

[21] McIlvaine, R. and James, A. (2010) The Potential of Shale Gas. World Pumps, 7, 16-18. http://dx.doi.org/10.1016/S0262-1762(10)70195-4

[22] Lebre, E., Borghetti, J., Basto, L. and Lauria, T. (2010) Sustainable Expansion of Electricity Sector: Sustainability Indicators as an Instrument to Support Decision Making. Renewable and Sustainable Energy Reviews, 14, $422-429$.

[23] Holsapple, C.V. and Singh, M. (2001) The Knowledge Chain Model: Activities for Competitiveness. Expert Systems with Applications, 20, 77-98. http://dx.doi.org/10.1016/S0957-4174(00)00050-6

[24] Shina, M., Holden, R. and Schmidt, R.A. (2001) From Knowledge Theory to Management Practice: Towards an Integrated Approach. Information Processing \& Management, 37, 335-355. http://dx.doi.org/10.1016/S0306-4573(00)00031-5

[25] Liao, W., Heijungs, R. and Huppes, G. (2011) Is Bioethanol a Sustainable Energy Source? An Energy-, Exergy-, and Emergy-Based Thermodynamic System Analysis. Renewable Energy, 36, 3479-3487. http://dx.doi.org/10.1016/j.renene.2011.05.030

[26] Luo, L., Van Der Voet, E. and Huppes, G. (2009) Life Cycle Assessment and Life Cycle Costing of Bioethanol from Sugarcane in Brazil. Renewable and Sustainable Energy Reviews, 13, 1613-1619. http://dx.doi.org/10.1016/j.rser.2008.09.024

[27] Hanff, E., Dabat, M.-H. and Blin, J. (2011) Are Biofuels an Efficient Technology for Generating Sustainable Development in Oil-Dependent African Nations? A Macroeconomic Assessment of the Opportunities and Impacts in Burkina Faso. Renewable and Sustainable Energy Reviews, 15, 2199-2209.

[28] Koh, M.Y. and Ghazi, T.I.M. (2011) A Review of Biodiesel Production from Jatropha curcas L. Oil. Renewable and Sustainable Energy Reviews, 15, 2240-2251. http://dx.doi.org/10.1016/j.rser.2011.02.013

[29] Kinnaman, T.C. (2011) The Economic Impact of Shale Gas Extraction: A Review of Existing Studies. Ecological Economics, 70, 1243-1249. http://dx.doi.org/10.1016/j.ecolecon.2011.02.005

[30] Arthur, J.D., Hochheiser, H.W. and Coughlin, B.J. (2011) State and Federal Regulation of Hydraulic Fracturing: A Comparative Analysis. Proceedings of the SPE Hydraulic Fracturing Technology Conference, The Woodlands, Texas, 24-26 January 2011.

[31] Lafollette, R.F. and Holcomb, W.D. (2011) Practical Data Mining: Lessons Learned from the Barnett Shale of North Texas”. Proceedings of the SPE Hydraulic Fracturing Technology Conference, The Woodlands, Texas, 24-26 January 2011.

[32] BP Statistical Review of World Energy 2014. http://www.bp.com/en/global/corporate/about-bp/energy-economics/statistical-review-of-world-energy.html

[33] Eurostats (2014) Energy Price Statistics. http://epp.eurostat.ec.europa.eu/statistics_explained/index.php/Energy_price_statistics

[34] European Union Directive 2009/28 CE. http://eur-lex.europa.eu/legal-content/EN/ALL/?uri=CELEX:32009L0028

[35] Brundtland, G. (1987) Our Common Future. Report, United Nations World Commission on Environment and Development. Oxford University Press, UK.

[36] IPCC, Mitigation of Climate Change. http://report.mitigation2014.org/spm/ipcc_wg3_ar5_summary-for-policymakers_approved.pdf

[37] Gellings, P.J. and Bouwmeester, H.J. (1997) Handbook of Solid State Electrochemistry. CRC Press, Boca Raton.

[38] Brandon, N.P. and Thompsett, D. (2005) Fuel Cells Compendium. Elsevier, Oxford. 
[39] Ference Weiker \& Company Ltd. (2010) Assessment of the Economic Impact of the Canadian Hydrogen and Fuel Cell Sector. British Columbia Ministry for Technology and Economic Development.

[40] Godo, H., Nedrum, L., Rapmund, A. and Nygaard, S. (2003) Innovations in Fuel Cells and Related Hydrogen Technology in Norway-OECD Case Study in the Energy Sector. NIFU Report 35/2003.

[41] Wyld Group Pty Ltd. (2008) Hydrogen Technology Roadmap. Australian Government, Department of Resources, Energy and Tourism, ABN:53099078485.

[42] Ormerod, M. (2003) Solid Oxide Fuel Cells. Chemical Society Reviews, 32, 17-28. http://dx.doi.org/10.1039/b105764m

[43] Park, S., Vohs, J.M. and Gorte, R.J. (2000) Direct Oxidation in a Solid-Oxide Fuel Cell. Nature, 404, 265-267.

[44] Tse, L.K.C., Wilkins, S., McGlashan, N., Urban, B. and Martinez-Botas, R. (2011) Solid Oxide Fuel Cell/Gas Turbine Trigeneration System for Marine Applications. Journal of Power Sources, 196, 3149-3162. http://dx.doi.org/10.1016/j.jpowsour.2010.11.099

[45] Turton, H. (2006) Sustainable Global Automobile Transport in the 21st Century: An Integrated Scenario Analysis. Technological Forecasting \& Social Change, 73, 607-629. http://dx.doi.org/10.1016/j.techfore.2005.10.001

[46] Thomas, C.E. (2009) Fuel Cell and Battery Electric Vehicles Compared. International Journal of Hydrogen Energy, 34, 6005-6020. http://dx.doi.org/10.1016/j.jjhydene.2009.06.003

[47] Van Mierlo, J., Maggetto, G. and Lataire, Ph. (2006) Which Energy Source for Road Transport in the Future? A Comparison of Battery, Hybrid and Fuel Cell Vehicles. Energy Conversion and Management, 47, 2748-2760.

[48] Moriarty, P. and Honnery, D. (2008) Low-Mobility: The Future of Transport. Futures, 40, 865-872. http://dx.doi.org/10.1016/j.futures.2008.07.021

[49] Moriarty, P. and Honnery, D. (2008) The Prospects for Global Green Car Mobility. Journal of Cleaner Production, 16, 1717-1726. http://dx.doi.org/10.1016/j.jclepro.2007.10.025

[50] Mullen, M. (2010) The State of Shale Plays in Europe. World Oil, 231, D-79.

[51] Editorial News (2011) Quebec's Shale-Gas Moratorium. Petroleum Economist, 78.

[52] Deluchi, M.A., Wang, Q. and Sperling, D. (1989) Electric Vehicles: Performance, Life Cycle Costs, Emissions and Recharging Requirements. Transportation Research, 23A, 255-270.

[53] Schot, J., Hoogma, R. and Elzen, B. (1994) Strategies for Shifting Technological Systems: The Case of the Automobile System. Futures, 26, 1060-1076. http://dx.doi.org/10.1016/0016-3287(94)90073-6

[54] Ford, A. (1994) Electric Vehicles and the Electric Utility Company. Energy Policy, 22, 555-570. http://dx.doi.org/10.1016/0301-4215(94)90075-2

[55] Plowshare Project. https://www.osti.gov/opennet/reports/plowshar.pdf 